\title{
Computer Vision Syndrome among Call Center Employees at Telecommunication Company in Bandung
}

\author{
Ghea Nursyifa, ${ }^{1}$ Putri Teesa Radhiyanti Santoso, ${ }^{2}$ Ine Renata Musa ${ }^{3}$ \\ ${ }^{1}$ Faculty of Medicine Universitas Padjadjaran ${ }^{2}$ Department of Physiology Faculty of Medicine \\ Universitas Padjadjaran, ${ }^{3}$ Department of Ophthalmology Faculty of Medicine Universitas \\ Padjadjaran/National Eye Center, Cicendo Eye Hospital Bandung
}

\begin{abstract}
Background: The occurrence of Computer Vision Syndrome (CVS) at the workplace has increased within decades due to theprolonged use of computers. Knowledge of CVS is necessary in order to develop an awareness of how to prevent and alleviate itsprevalence. The objective of this study was to assess the knowledge of CVS among call center employees and to explore the most frequent CVS symptom experienced by the workers.

Methods: A descriptive cross sectional study was conducted during the period of September to November 2014 at Telecommunication Company in Bandung using a questionnaire consisting of 30 questions. Out of the 30 questions/statements, 15 statements were about knowledge of CVS and other 15 questions were about the occurrence of CVS and its symptoms. In this study 125 call center employees participated as respondents using consecutive sampling. The level of knowledge was divided into 3 categories: good (76$100 \%)$, fair (75-56\%) and poor ( $<56 \%)$. The collected data was presented in frequency tabulation.

Results: There was $74.4 \%$ of the respondents had poor knowledge of CVS. The most symptom experienced by the respondents was asthenopia.

Conclusions: The CVS occurs in call center employees with various symptoms and signs. This situation is not supported by good knowledge of the syndrome which can hamper prevention programs. [AMJ.2016;3(2):181-5]
\end{abstract}

Keywords: Call center employees, Computer Vision Syndrome, knowledge

\section{Introduction}

A prolonged computer use may cause vision problems and eye discomfort, namely Computer Vision Syndrome (CVS). ${ }^{1,2}$ The level of discomfort seems to increase with the amount of computer use. ${ }^{1}$

The American Optometric Association (AOA) describes CVS as a group of eye and vision-related problems that result from prolonged computer use. ${ }^{1}$ Blehm et $\mathrm{al}^{3}$ classified CVS symptoms into four main categories; asthenopia, ocular surface, visual, and extra ocular symptoms. Most of the symptoms are temporary and will disappear after the computer user stops working with thecomputer, yet the symptoms remain in some individuals. ${ }^{4}$

Moreover, CVS occurs in $70-75 \%$ of computer users. ${ }^{4}$ Even though this syndrome is not life threatening and no research has proven nor confirmed that CVS might cause permanent eye damage or harm an individual's life, the occurrence of this syndrome may disturb work productivity. ${ }^{5}$ The call center employee has a high risk on experiencing CVS due to excessive work demands and prolonged exposure to the computer screen. ${ }^{6}$

Hence, sufficient knowledge about CVS especially about its prevention is essential in order to enhance theindividual's awareness about the proper timing in using computers and most importantly about visual ergonomic so that it can minimize or prevent the occurrence of CVS.7 The objective of this study was to assess the knowledge of CVS among call center employees and to explore the most frequent symptom experienced by them.

\section{Methods}

A descriptive cross sectional approach was

Correspondence: Ghea Nursyifa, Faculty of Medicine, Universitas Padjadjaran, Jalan Raya Bandung-Sumedang Km.21, Jatinangor, Sumedang, Indonesia, Phone: +62 8562200155 Email: gheanursyifa8@yahoo.com 
Table 1 Demographic Profile of Respondents

\begin{tabular}{lcc}
\hline & Frequency $(\mathbf{n = 1 2 5})$ & Percentage (\%) \\
\hline Gender & & 48.8 \\
Male & 61 & 51.2 \\
Female & 64 & 65.6 \\
Age (year) & & 32.8 \\
$<25$ & 82 & 1.6 \\
$25-40$ & 41 & 73.6 \\
$>40$ & 2 & 13.6 \\
Level of Education & & 12.8 \\
High School & 92 & \\
Diploma & 17 & \\
Bachelor & 16 & \\
\hline
\end{tabular}

used in this study. This study was conducted at the Telecommunication Company in Bandung during the period of September to November 2014 with call center employees as the respondents. Based on the minimal sample size calculation, 125 respondents were included in this study using theconsecutive sampling technique. Respondents who had filled the questionnaire incompletely were excluded.

The validated and translated questionnaire consisting of 30 questions was used in this study. ${ }^{7,8}$ Out of the 30 questions/statements, 15 statements were about knowledge of CVS and other 15 questions were about the occurrence of CVS and its symptoms. The level of knowledge was divided into 3 categories, i.e. good (76-100\%), fair (75-56\%) and poor $(<56 \%){ }^{9}$ The collected data was presented in frequency tabulation.

\section{Results}

The demographic data of respondents was assessed by sex, age, and educational level (Table 1). The table shows that thepercentage of female call center employees was similar to the percentage of male call center employees. Most of the respondents were aged less than 25 years and from high school level.
Knowledge of CVS was classified into three categories which are good, fair, and poor (Table 2). The Table shows that most of the respondents had poor knowlege of CVS and none of them had good knowledge.

Knowledge of CVS was assessed by the aspects of definition, etiology, risk factor, sign and symptom, prevention, complication, and visual ergonomics (Table 3). The table shows that $97.6 \%$ respondents knew about the definition of CVS but only $16 \%$ knew about the complication of CVS.

The symptom of CVS perceived by respondents were divided into four main symptoms; asthenopia, ocular surface, visual, and extraocular symptoms ${ }^{3}$ (Table 4). Based on Table 4, 77.8\% respondent experienced eye fatigue and the least symptom experienced by the respondent was hard to focus counts.

\section{Discussion}

The knowledge of CVS among call center employees was poor. A study conducted by Akinbinu et al. ${ }^{7}$ in Nigeria showed a similar result. The percentage of respondents who had sufficient knowledge was only $27 \%$, and only $40 \%$ of them had awareness of the occurrence of CVS. In contrast to a study conducted by

Table 2 Level of CVS Knowledge

\begin{tabular}{lcc}
\hline Score & Frequency $(\mathbf{n = 1 2 5})$ & Percentage $(\%)$ \\
\hline Good $(76-100 \%)$ & 0 & 0 \\
Fair $(75-56 \%)$ & 32 & 25.6 \\
Poor $(<56 \%)$ & 93 & 74.4 \\
\hline
\end{tabular}


Ghea Nursyifa, Putri Teesa Radhiyanti Santoso, Ine Renata Musa: Computer Vision Syndrome among Call 183 Center Employees at Telecommunication Company in Bandung

Table 3 Assessment of CVS based on Components of CVS Knowledge

\begin{tabular}{lcccc}
\hline \multirow{2}{*}{\multicolumn{1}{c}{ CVS Theory }} & \multicolumn{4}{c}{ Respondents' answer } \\
\cline { 2 - 5 } & \multicolumn{2}{c}{ Correct } & \multicolumn{3}{c}{ Incorrect } \\
\cline { 2 - 5 } & $\mathrm{n}$ & $\%$ & $\mathrm{n}$ & $\%$ \\
\hline Definition & 122 & 97.6 & 3 & 2.4 \\
Etiology & 31 & 24.8 & 94 & 75.2 \\
Risk Factor & 37 & 29.6 & 88 & 70.4 \\
Sign and Symptom & 31 & 24.8 & 94 & 75.2 \\
Prevention & 21 & 16.8 & 104 & 83.2 \\
Complication & 20 & 16 & 105 & 84 \\
Visual Ergonomics & 37 & 29.6 & 88 & 70.4 \\
\hline
\end{tabular}

Zainuddin and $\mathrm{Isa}^{10}$ in Malaysia, there were only $35.6 \%$ of respondents who had poor knowledge about CVS.

Almost all respondents knew the definition of CVS but only a few were aware of theetiology, causes, risk factors, symptoms, prevention, complications, and visual ergonomics. According to a research conducted by Mujaddidi ${ }^{11}$ in Semarang showed that none of the respondents were aware of the risk factors of the CVS incidence. A research conducted by Chiemeke et al. ${ }^{12}$ in Nigeria showed that only $32 \%$ of respondents knew about theprevention of CVS.

Furthermore, another research on visual ergonomics conducted by Zainuddin and Isa $^{10}$ in Malaysia showed that the respondents had less knowledge about visual ergonomics. A similar study conducted by Khan et al. ${ }^{13}$ in Pakistan showed that only $30 \%$ were aware of the visual ergonomics at the workplace. A previous study conducted by Logaraj et al. ${ }^{14}$ in

Table 4 Symptoms of CVS

\begin{tabular}{lcc}
\hline Symptoms & Frequency $\mathbf{( n = 1 0 7 )}$ & Percentage (\%) \\
\hline Asthenopia & & \\
Eye Fatigue & 97 & 77.6 \\
Eye Strain & 24 & 19.2 \\
Eye Pain & 38 & 30.4 \\
Dry Eye & 42 & 33.6 \\
Headache & 57 & 45.6 \\
Ocular Surface & & \\
Watery eye & 60 & 48 \\
Irritation & 52 & 41.6 \\
Visual & & \\
Blurred Vision & 48 & 38.4 \\
Doubled Vision & 32 & 25.6 \\
Hard to Focus & 2 & 1.6 \\
Extra ocular & & \\
Neck pain & 51 & 40.8 \\
Shoulder pain & 54 & 43.2 \\
Back pain & 59 & 47.2 \\
\hline
\end{tabular}


Chennai found that only $58.7 \%$ of respondents applied appropriate visual ergonomics, in the form of an ideal distance eye with monitor.

A poor knowledge of CVS among respondents in this company might be caused by two factors. Firstly, the terminology of CVS was unfamiliar in the community, meanwhile AOA stated that approximately $70-75 \%$ of computer users experienced CVS symptoms. Secondly, there has never been a socialization program about CVS among them. In fact, a call center occupation is one of the jobs that is frequently exposed to a monitor that has a high risk to experience CVS. ${ }^{6}$ Good knowledge of CVS especially about its prevention may help to reduce the number of incidence of CVS in a population.?

The most complaint perceived by the respondents was asthenopia. This result is consistent with a similar study conducted by Bali et al. ${ }^{15}$ in India, Franz and Erizone ${ }^{16}$ in Jakarta and Reddy et al. ${ }^{17}$ in Malaysia.

The vision problem which occurred when an individual works in front of a computer iscaused by the combination of the vision problems owned by the individual and poor ergonomics. Those might cause uncomfortable working environment and an unfavorable attitude while working in front of thecomputer. ${ }^{18}$

Moreover, a previous research conducted by Zakiuddin and Isa ${ }^{10}$ in Malaysia showed that $50 \%$ of respondents indicated a bad habit in using a computer at the workplace. A similar study conducted by Mvungi et al. ${ }^{19}$ in Africa showed that the occurrence of CVS was mainly caused by poor knowledge about the proper attitude when working with the computer.

The occurrence of CVS among respondents was high however, the knowledge about it is still poor, the respondents were unaware that they suffered from CVS and they also, did not know about its prevention. If CVS is left untreated it might cause an individual to experience obstacles in their daily activities, decrease work productivity, increase in the level of error in their work, as well as a decrease in job satisfaction. ${ }^{4}$

This study had limitations, among others were the sampling method and the number of questions about the knowledge of CVS. The consecutive sampling was performed because firstly, the sample size was too large; secondly, the questionnaire should be filled out under supervision and should not be taken home. Due to different shift work schedules it was quite difficult for the researcher to meet with the night shift respondents.
Based on this study, it can be concluded that the knowledge of CVS among call center employees is still poor. The most sign and symptom experienced by the workers were asthenopia.

For further research, the sampling method should be conducted randomly in order to avoid a biased selection and give equal opportunity to all employees to be included in the study. The company should be more concerned about the occurrence of CVS among the workers because it can affect the quality and productivity of the workers in the workplace. Good knowledge about CVS is necessary to conduct early prevention.

\section{References}

1. American Optometric Assosciation. Computer vision syndrome. 2011 [Cited 2014 Jun 7]. Available from http://www. aoa.org/patients-and-public/caringfor-your-vision/protecting-your-vision/ computer-vision-syndrome

2. Madhan MR. Computer vision syndrome. The Nursing Journal of India. 2009;C(10):236-7.

3. Blehm C, Vishnu S, Khattak A, Mitra S, Yee RW. Computer vision syndrome: a review. Surv Ophthalmol. 2005; 50(3):253-62

4. American Optometric Association. The effects of video display terminal use on eye health and vision. 2011 [cited 2014 Jun 4]. Available from: http://www.aoa.org/ $\mathrm{x} 5380 . \mathrm{xml}$

5. Charpe NA, Kaushik V. Computer vision syndrome (cvs): recognition and control in software professionals. J Hum Ecol. 2009;28(1):67-9.

6. Australian Government Comcare. Call Centres: a guide to safe work. Canberra: Commonwealth of Australia; 2012.

7. Akinbinu TR, Mashalla YJ. Knowledge of computer vision syndrome among computer users in the workplace in Abuja, Nigeria. J Physiol Pathophysiol. 2013;4(4):58-63.

8. Azkadina A. Hubungan antara faktor risiko individual dan komputer terhadap kejadian computer vision syndrome [Undergraduate Thesis]. Semarang: Universitas Diponogoro; 2012.

9. Rustaman NY. Basic science inquiry in science education and its assessment. Seminar Proceeding of The First International Seminar of Science Education; 2007 October 27; Bandung. 2007. 
10. Zainuddin $\mathrm{H}$, Isa MM. Effect of human and technology interaction: computer vision syndrome among administrative staff in a public university. International Journal of Business, Humanities and Technology. 2014;4(3):38-44.

11. Mujaddidi HRA. Analisis faktor-faktor terhadap kejadian computer vision syndrome (CVS) pada pekerja layout editor di CV. X TembalangKota Semarang. Jurnal Kesehatan Masyarakat. 2012;1(2):731-7.

12. Chiemeke SC, Akhahowa AE, Ajayi OB. Evaluation of vision-related problems amongst computer users: a case study of University of Benin, Nigeria. Proceedings of the world congress on Engineering; 2007 July 2-4; London. 2007.

13. Khan R, Surti A, Rehman R, Ali U. Knowledge and practices of ergonomics in computer users. J Pak Med Assoc.2012;62(3):213-7.

14. Logaraj M, Priya VM, Seetharaman N, Hedge SK. Practice of ergonomic principles and computer vision syndrome (CVS) among undergraduates students in Chennai.
National Journal of Medical Research. 2013;3(2):111-6.

15. Bali J, Navin N, Thakur BR. Computer vision syndrome: a study of the knowledge, attitude and practices in Indian Ophthalmologists. Indian J Ophthalmol. 2007;55(4): 289-94.

16. Suharyanto FX, Safari E. Asthenopia pada pekerja wanita di Call Centre-X. Bul Penelit Kesehat. 2010;38(3):119-30.

17. Reddy SC, Low CK, Lim YP, Low LL, Mardina F, Nursaleha MP. Computer vision syndrome: a study of knowledge and practices in university students. Nepal J Ophthalmol. 2013;5(2):161-8

18. Anshel J, editor. Visual ergonomics handbook. Boca Raton: CRC Press; 2005.

19. Mvungi VP, Mcharo J, Mmbuji ME, Mgonja LE, Kitua AY. Health hazards related to computer use: experience of the national institute for medical research in Tanzania. International Journal of Social, Behaviour, Educational, Bussines and Industrial Engineering. 2008;2(12):1283-8. 